\title{
Stems extract of kemuning cina (catharanthus roseus) as biofungicides against white root fungal (rigidoporus microporus) of rubber trees (hevea brasiliensis).
}

\begin{abstract}
White root disease which cause by Rigidoporus Microporus fungus are the most destructive and serious disease among the three major root disease in rubber plantation. Biological control using stems extract of kemunting cina (Catharanthus roseus) have been used as a healing agent of infected rubber trees. The objectives of the study are to determine the ability of stems extract from kemunting cina to control white root disease of rubber trees and to observe the plants performance towards the fungus. Stems of the plant were soaked in dichloromethane (DCM) solution because the solvent was found as the best extraction for the treatments. Three batches of rubber trees were prepared in the research, which consists of five trees. Group A was a control, while the trees in Group B were planted with fungus and the trees in Group $\mathrm{C}$ was applied with the stems extract together with the fungus. Five hundred $\mathrm{ml}$ of extracts was used as biofungicides against white root disease. The chlorophyll, diameter, height and number of leaves were recorded. Among the three groups of rubber trees, Group $\mathrm{C}$ shows the ability of extract to inhabit against Rigidoporus Microporus growth refers to the improvement of growth performance of the plants. The stem extracts of kemunting cina were antagonistic inhibited against Rigidoporus microporus fungus.
\end{abstract}

Keyword: White root disease; Rigidoporus microporus; Kemunting cina (Catharanthus roseus); Dichloromethane; Biological control. 